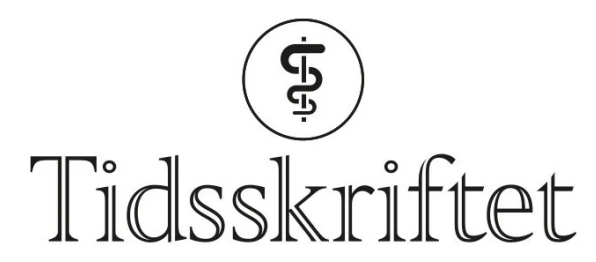

DEN NORSKE LEGEFORENING

\title{
Psykiatrien trenger et løft - ikke tomme løfter
}

DEBATT

LARS LIEN

ANNE KRISTINE BERGEM

Anne Kristine Bergem er spesialrådgiver i Norsk psykiatrisk forening. Forfatteren har fylt ut ICMJE-skjemaet og oppgir ingen interessekonflikter.

\section{Nå trenger vi en helseminister som ser betydningen av psykiatriens samfunnsoppdrag og rammer og som gjør det mulig å skape et faglig løft.}

20-25\% av befolkningen får en psykisk lidelse i løpet av et år (11). I tillegg er det sannsynligvis en stor grad av underdiagnostisering, særlig av alkohol- og andre misbrukslidelser. Gapet i levealder mellom dem med og uten en psykisk sykdom er på 1020 år, og enda høyere for dem med både psykisk sykdom og ruslidelse (므). Tidlig død skyldes i noen tilfeller selvmord og andre årsaker knyttet til psykisk lidelse, men majoriteten av de tapte leveårene skyldes hjerte- og karsykdom og lungelidelser - som igjen er relatert til levekår. Personer med psykiske lidelser har i gjennomsnitt lavere utdanningsnivå og dårligere økonomi enn resten av befolkningen, i tillegg til en mindre helsefremmende livsstil.

Fra 2009 til 2018 har den gjennomsnittlige liggetiden i psykisk helsevern gått ned fra 27 til 18 liggedøgn. Nedgangen tilsvarer en reduksjon på i overkant av $30 \%$, og den fortsetter (3). Liggetiden er i dag for kort til å kunne utrede og behandle pasienten og etablere et godt tverrfaglig samarbeid rundt videre oppfølging. Utredning og behandling av somatiske, livsvilkårsrelaterte sykdommer er et av de feltene som særlig lider når tid og ressurser mangler. Pakkeforløpene skulle bidra til mindre variasjon i behandlingstilbudet og bedre ivaretakelse av fysisk helse så vel som psykisk, men mange pasienter i spesialisthelsetjenesten møter knapt en lege/psykiater i løpet av forløpet. I tillegg er samarbeidet mellom spesialist- og kommunehelsetjenesten i liten grad bestemt av forskrifter og retningslinjer. 


\section{"Helseministerens tiltredelseserklcering til psykiatrien var at veksten $i$ \\ psykisk helsevern skulle vare like høy som i somatikken. Det har ikke \\ skjedd»}

For de fleste helseforetak bruker $10 \%$ av pasientene ca. $75 \%$ av ressursene i den psykiatriske delen av spesialisthelsetjenesten (4.). Disse pasientene har langvarige og kompliserte tilstander. Flere senger ville gjort det mulig å legge inn pasienter tidligere (frivillig), før tilstanden forverrer seg og tvang blir nødvendig. Tid og finansiering som stimulerer til samarbeid mellom ulike instanser, vil også her være avgjørende for bedring av kvalitet i tjenestene.

Mer enn 300 psykiaterstillinger er ubesatt i Norge. Vikarer dekker 50 \% av dem. Halvparten av lederne sliter med rekruttering, og nesten 70 \% uttrykker behov for flere psykiaterstillinger (5). Helseministerens tiltredelseserklæring til psykiatrien var at veksten i psykisk helsevern skulle være like høy som i somatikken (den gylne regel). Det har ikke skjedd. Veksten har vært nesten tre ganger høyere i somatikken i alle årene til Bent Høie (ㅁ). En grunn til at somatikken seirer i budsjettkampen hvert år, er vakante stillinger i psykiatrien. En annen er at det er lettere å øke inntjeningen i somatikken. Der er den innsatsstyrte finansieringen høyere ( $50 \%$ versus $20 \%$ ), noe som betyr at en øyespesialist tjener inn sin egen lønn og mer enn det.

\section{Faglig og ressursmessig løft}

Kort liggetid og manglende ressurser gjør at pasienter og pårørende ofte selv må sørge for å integrere egne tjenester. Et viktig element i pakkeforløpene var at pasientforløpene skulle koordineres bedre, men uten av det fulgte ressurser med forløpskoordineringen. Nå viser evalueringen av pakkeforløpene at nærmere $70 \%$ av lederne ikke prioriterer forløpskoordinering (7.). Insentivordningene, særlig innsatsstyrt finansiering (ISF), favoriserer korte polikliniske konsultasjoner og utbygging av polikliniske tilbud, noe som igjen medfører mer papirarbeid og produksjonskrav for personalet.

\section{"For å bedre arbeidsforholdene for spesialister er det behov for tiltak som \\ å øke antallet turnusplasser med tjeneste i psykiatrien samt øke antall utdanningsstillinger for leger i psykiatri»}

På bekostning av spesialisthelsetjenesten har kommunene fått større ansvar og ressurser til behandling, men staten kan i liten grad følge opp hvordan midlene brukes. Det har vært en $31 \% ø$ kning av kommunale tjenester til dem under 17 år og $19 \%$ til dem over, samtidig som det har vært nedgang i poliklinisk og døgnbasert behandling både blant barn og voksne i spesialisthelsetjenesten (ㅁ). Pakkeforløpet skulle hindre uønsket variasjon, men det er uklart hvordan dette sikres i kommunene. En ny opptrappingsplan med øremerkede midler kan synes nødvendig.

Manglende rekruttering av spesialister bidrar til økt arbeidsbelastning på resterende kolleger. Mange psykiatere er ofte eneste lege på en enhet og savner kollegaer å drøfte med. Psykiatere bruker i dag ca. 50 \% av tiden på dokumentasjon (5). Forenklet journalføring og mindre utfylling av skjemaer vil kunne gi økt tid til pasientarbeid. For å bedre arbeidsforholdene for spesialister er det behov for både korte og langsiktige tiltak som å $\emptyset \mathrm{ke}$ antallet turnusplasser med tjeneste i psykiatrien samt $\varnothing \mathrm{ke}$ antall utdanningsstillinger for leger i psykiatri. 
Norske psykiatere ønsker å gi et best mulig tilbud til sine pasienter, men da må rammebetingelsene være til stede. Det må være tid og ressurser til å ta seg av hele mennesket.

\section{LITTERATUR}

1. Folkehelseinstituttet. Psykiske lidelser hos voksne. https://www.fhi.no/nettpub/hin/psykiskhelse/psykiske-lidelser-voksne/?term $=\& \mathrm{~h}=1$ Lest 27.6.2021.

2. Lien L, Huus G, Morken G. Psykisk syke lever kortere. Tidsskr Nor Legeforen 2015; 135: 246-8. [PubMed][CrossRef]

3. Statistisk sentralbyrå. Kortere liggetid i psykisk helsevern. https://www.ssb.no/helse/artikler-ogpublikasjoner/kortere-liggetid-i-psykisk-helsevern Lest 27.6.2021.

4. Pasientgrupper med omfattende tjenestebehov. NHSP-analyse 3. Rapport IS-2732. Oslo:

Helsedirektoratet, 2018. https://www.helsedirektoratet.no/rapporter/pasientgrupper-medomfattende-tjenestebehov/Rapport\%20NHSP\%203\%20-

\%2oPasientgrupper\%2omed\%2oomfattende\%2obruk\%20-

\%2oendelig.pdf/_/attachment/inline/e2d8b2bd-afb4-4c36-a940-

968obgoe5bdd:d5dob4ac73abe1826ebdoad18fe78335638596of/Rapport\%20NHSP\%203\%2O-

\%2oPasientgrupper\%2omed\%2oomfattende\%2obruk\%20-\%2oendelig.pdf Lest 27.6.2021.

5. Den norske legeforening. Legebarometeret: Rekrutteringskrise blant både fastleger og psykiatere https://www.legeforeningen.no/nyheter/2021/legebarometeret-rekrutteringskrise-blant-badefastleger-og-psykiatere/ Lest 27.6.2021.

6. Riksrevisjonen. Undersøkelse av psykiske helsetjenester. https://www.riksrevisjonen.no/rapportermappe/no-2020-2021/undersokelse-av-psykiske-helsetjenester/ Lest 27.6.2021.

7. Helsedirektoratet. Evaluering av pakkeforløp psykisk helse- og rus. https://www.helsedirektoratet.no/nyheter/evaluering-av-pakkeforlop-psykisk-helse-og-rus Lest 27.6.2021.

Publisert: 19. august 2021. Tidsskr Nor Legeforen. DOI: 10.4045/tidsskr.21.0532

Mottatt 2.7.2021, første revisjon innsendt 11.8.2021, godkjent 15.8.2021.

(C) Tidsskrift for Den norske legeforening 2023. Lastet ned fra tidsskriftet.no 26. april 2023. 